\title{
Planning and regulation of pre-final cuttings in Poland - a proposal for change
}

\author{
Tomasz Borecki ${ }^{1}$, Dariusz Pieniak ${ }^{2}$, Edward Stęieńn ${ }^{1}$, Roman Wójcik $^{1} \bowtie$ \\ ${ }^{1}$ Warsaw University of Life Sciences, Faculty of Forestry, Department of Forest Management Planning, Geomatics \\ and Forest Economics, Nowoursynowska 159,02-776 Warsaw, Poland, e-mail: roman.wojcik@wl.sggw.pl \\ ${ }^{2}$ University of Łódź, Branch in Tomaszów Mazowiecki, Institute of Forest Sciences, Konstytucji 3 Maja 65/67, \\ 97-200 Tomaszów Mazowiecki, Poland
}

\section{Abstract}

Scheduling and regulation of the forest use are of much importance in forest management. Decisions regarding the manner, timing, and intensity of tree felling result in long-term effects, as these affect the species and age structure of forests, along with the direction and dynamics of changes in forest resources. Above all, serious doubts concern the way of determining and accounting for the prescribed forest utilization, and in particular, the possibilities of the pre-final cuttings. In recent times, the precise determination of the pre-final cuttings by volume has been given up. According to the law, the area of pre-final cuttings is now obligatory taken into account. Consequently, it is not possible to determine the total volume limiting the amount of timber to be harvested, thus, there is decreased the value of the forest management plan as the document approved by the minister responsible for forestry as well as the basis for forest management. For practical reasons, the specified pre-final cuttings by volume are considered as indicative.

Connecting the planned pre-final cutting volume with the expected volume increment of the stand has not been relinquished. In the present paper, the authors called attention to a necessity for further improvement of the mediumterm planning of pre-final cutting volume. A need to change the definition of the incidental cutting was emphasized. As said by the authors, the term "incidental cutting" should denote harvesting wood from diseased and dying or dead trees, along with eliminating the effects of tree damage caused by fortuitous events. Accordingly, the incidental cuttings that are inherently unpredictable, should not be directly attributed to pre-final cutting products. Keeping in mind the incidental cuttings, the authors proposed the method of reckoning the forest use, which would allow for correct accounting with regard to the prescribed pre-final cuttings.

\section{KeY WORDS}

forest management plan, planning and regulation, pre-final and final cuttings, incidental cutting 


\section{INTRODUCTION}

Conditions for the planning and rational forest management have been documented for nearly 300 years, by means of the concept of forest sustainability (Zuercher 1965). In the initial period, sustainability was defined, mainly in terms of forest production function, as "Durability-Continuity-Uniformity". In the 1700 s and $1800 \mathrm{~s}$, there took place dynamic development of industry, agriculture, and trade, resulting in significantly increased wood demand. Consequently, the principle of sustainability became a tool for safeguarding central Europe's forests devastated by excessive logging (Kurt 1993). The idea of forest sustainability continues to exert a strong influence on the direction of forestry advancement, especially in view of the concept of sustainable development (Oesten 1993; Stępień 1995; Poznański 1996). Forest management planning largely supports the implementation of sustainability objectives (Szymkiewicz et al. 1996; Stępień 1998). In practice, the realization of these tasks means the preparation of forest management plans. The need for planning, in both temporal and spatial sense, is justified by forestry specifics, among others: large-area forests, diverse natural conditions, and long production periods in conjunction with the associated difficulty in determining the maturity of the product and the extent of its use.

In forest management, the planning and regulation of the forest use take a special place (Borecki et al. 2016). Decisions regarding the manner, timing, and intensity of the cutting carried out cause long-term effects, influencing species and age structure of the forest, as well as the directions and dynamics of changes in its resources (Rosa and Smykała 1985; Pieniak 2008; Borecki and Stępień 2012; Borecki et al. 2016).

The final cuttings, particularly in clearcut areas, involve harvesting of mature crops. The problem of planning and regulation becomes more complex in the case of pre-final cutting (Rutkowski 1971, 1988; Pieniak 2008; Borecki et al. 2016). The amount of the latter depends on the needs of the silvicultural system, which are often burdened by the subjective sense of the valuator at the stage of tree evaluations during the forest taxation. This is particularly true for young developmental stages of stands, which usually require 2 thinning treatments in 10 years. At that time, only the type, need and ur- gency of cuttings in conjunction with the area of treatments are stated.

The actual amount of pre-final cuttings is known only at the time of performing these treatments. Therefore, the pre-final cutting volume planned was perceived as an indicative forecast only. However, the evaluated volume of the pre-final cuttings was losing its indicative character when combined with that of final cuttings, to become a component of the total yield harvested - approved by the minister with the clause that it was the maximum volume and could not be exceeded during the management term. These circumstances were the main prerequisite for analyzing the issues related to the planning and regulation of the forest use under current forestry conditions in Poland, with particular regard to the specificity of accounting for the pre-final and incidental cuttings.

\section{Actual state of affairs}

In the regulatory orders regarding the approval procedure for forest management plans, in effect until recently, the total yield determination by volume (pre- and final cuttings) meant the maximum amount of timber expected to be obtained in 10 years. This connoted that in the case of larger than the planned pre-final cutting volumes (usually due to unforeseen reasons), there was a need to compensate, i.e. to stop the implementation of some planned items of the cutting plan. This is confirmed by data of the Directorate General of State Forests (Raport... 2006), presented in the table below.

Table 1. Planned and realized timber volumes in the State Forests in 1984-2003 (thousand $\mathrm{m}^{3}$ net large timber/year)

\begin{tabular}{|c|c|c|c|c|c|c|c|}
\hline Yea & 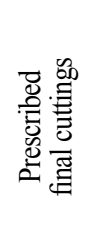 & 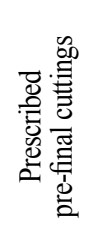 & $\begin{array}{l}\frac{0}{0} \\
\frac{1}{3} \\
0 \\
0 \\
0 \\
0\end{array}$ & 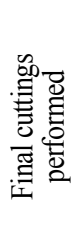 & 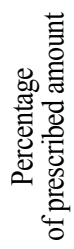 & 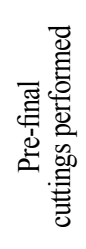 & 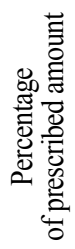 \\
\hline 1984 & 9,990 & 7,588 &, 578 & 8600 & 86.1 & 12,878 & 169.7 \\
\hline 1989-1993 & 9,297 & 8,034 & 17,331 & 8198 & 88.2 & 9,440 & 117.5 \\
\hline 1994 & 837 & 10,203 & 20,040 & 7653 & 77.8 & 11,773 & 115.4 \\
\hline 1999 & 10,850 & 12,446 & 23,296 & 9965 & 91.8 & 14,632 & 117.6 \\
\hline Average & 9,994 & 9,568 & 19,561 & 8601 & 86.1 & 12,181 & 127.3 \\
\hline
\end{tabular}


The analysis of the forest use in the period 1984-2003, indicated that the prescribed final cuttings were performed at a level about $86 \%$ on average, and the pre-final cuttings were about $127 \%$ of the prescribed amount. The discrepancies between the planned and implemented values, that persisted over such a long period of time, were certainly the reason for many negative consequences. The most important aspect was the need to compensate, and especially if it concerned discontinuation of subsequent stages of complex cuttings. Despite the effects of such proceedings on nature, suspension of planned cuttings significantly disturbed relations between the intensity of stand aging processes and progression of the logging process, which was the main reason of unfavorable changes in stand age structure (Borecki et al. 2016).

In the current Instruction for Forest Management (Instrukcja... 2012), there is a position on the prescribed cuttings - consistent with the desired direction of development and condition of wood resources. There is defined that the cuttings should amount to the sum of all cuttings in the stands of averaged age - performed in the whole Forest District. The authors of the present paper express the view that the provisions on the practical use of this position are not precise, and therefore, the use of this approach in the rational control of the direction of resource development is minor. This is evidenced by the fact that within the Forest District, the same average age of stands in disparate forest management units can be achieved with different (more or less relevant) age classes.

The main shortcoming in the planning and implementation of the pre-final cuttings, which causes large discrepancies between the planned and implemented values, is the miscellaneous opinion as to the incidental cuttings.

\section{THE ISSUE OF REGULATING INCIDENTAL UTTINGS}

According to the provisions of forest management instructions, the incidental cuttings constitute parts of the pre-final or final cuttings. This also applies to the Instructions issued in 2003 and 2012. Most often, the incidental cuttings are interpreted in such a way that any of these performed outside the areas planned for tree cuttings is treated as the pre-final cutting. This definition of the incidental forest use was derived from the forest management instruction obligatory in the year 1957 , according to which wood from the incidental cuttings was categorized as that obtained from the sanitation cuttings, carried out either individually or in groups, without the need of forest renovation in the sites after such treatments.

This situation required the adjustment of the so far method of accounting for the forest use. The need for revision in this regard has been taken into account in the Act on Forests (Journal of Laws, 1991, No. 101, item 444), currently in force. From the content of provisions of the Act, it follows that the amount of timber expected to be harvested shall be determined in the forest management plan separately as the pre-final cutting by volume and the prescribed pre-final cutting by area (Act on Forests, Art. 18, p. 4. 3). Hence, the incidental cutting shall not increase the realization of the prescribed pre-final cuttings by volume. Nevertheless, the above statement is not fully accurate and needs to be revised with respect to the issue of considering the prescribed pre-final cuttings in terms of their area, as well as accounting for the incidental cuttings.

In the context of the conditions presented above, it is crucial to separate the accounting for the prescribed final cuttings and those pre-final. The quantity of prefinal cuttings cannot impinge on completing the final cuttings. For the needs of forest management planning, this issue is governed by the provisions of the Regulation No. 30 of the General Director of the State Forests (Zarządzenie... 2014), which refers to the prescribed final cuttings as "the maximum harvestable amount during the life of a forest management plan" and the prescribed pre-final cuttings - as "the mandatory minimum area of the thinning cuttings (...), expressed in cubic meters, for the duration of the plan". It is also important to note the provision on a need for a separate accounting of implementation of both types of the prescribed cuttings "without a possibility of compensating harvested volumes", that allows an option of exceeding the volume of the prescribed pre-final cuttings, by the performance of the incidental cuttings on account of some forest disaster.

A separate issue was the limitation of the prescribed pre-final volume by adopting the maximum value of $50 \%$ of the expected volume increment of the respective stands (Konieczny and Zajączkowski 1990). This provi- 
sion was due to the fear of threatening the possibility of stockpiling in middle-aged stands (Rutkowski 1988). The study conducted in the Department of Forest Management, Warsaw University of Life Sciences - SGGW (Borecki et al. 2012), showed that this limitation was not always justified, and there are no reasonable grounds for its application. The obtained results confirmed that the forest use, expressed as percentage of volume increase, depends on stand age. In pine stands of younger age, the forest use grows rapidly from $6.28 \mathrm{~m}^{3} /$ ha in the age sub-class $\mathrm{Ib}$, to $24.57 \mathrm{~m}^{3} /$ ha in the age sub-class IVa, followed by a gradual decrease to $21.80 \mathrm{~m}^{3} /$ ha in stands of the age class VI and older.

When analyzing the pre-final cutting amount against the expected increase of the current stand volume, it was found that the younger the stand was, the lower was the ratio of the volume cut down to the current stand volume increment. In the age subclass $\mathrm{Ib}$, the value obtained was $9.01 \%$, whereas in the age class VI and older classes $-93.39 \%$. These values are comparable with the values reported by Konieczny and Zajączkowski (1990) who, on the basis of the "Tables for thinning cuts effectiveness", determined the range from $10 \%$ to $90 \%$, for a 20 -year-old stand and 100-year-old stand, respectively, both with full crown closure and the site class I.

There are large variations in the intensity of the thinning cuts in different regions of the country (Konieczny and Zajączkowski 1990). According to Rutkowski (1988), the intensity of such cuts depends on the subjective assessment of the evaluator. Research conducted by the Department of Forest Management WULS-SGGW confirms the above. The results obtained (Borecki et al. 2012) show that there are regional differences due to widely understood geographic, habitat and forest stand conditions. The results also confirm the assumption, that there is a subjective approach in the implementation of the pre-final cuttings, depending on the so-called "traditional school" as to tending intervention intensity. Pieniak (2008) states, that there is no rationale for using one indicator, i.e. $50 \%$ of the expected increase in the current stand volume, as the determinant of the maximum value of the pre-final cutting amount. On average, there was harvested approximately $44 \%$ of the volume increment (excluding the incidental cuttings), and in 228 of 775 analyzed forest localities, the cuttings exceeded $50 \%$ of the expected volume increment.
Thus, the analyzes carried out showed that the share of the pre-final cuttings depends on the age of tree stands and their natural conditions, as well as the decision of a given forest manager. In the areas with numerous older stands, the adoption of the maximum value for the pre-final cutting amount as $50 \%$ of the expected stand volume increment results in an underestimation of the prescribed pre-final cuttings. The consequence of this is the forest use disarrangement, which can result in long-lasting disturbance effects on forest management. In the areas, where pine average age is low, the use of the $50 \%$ index as the determinant for the prescribed prefinal cuttings will result in overestimation of the prefinal cuttings. It is assumed in the provisions of the new Instruction on Forest Management (Instrukcja... 2012) that the planned average amount of the pre-final cuttings should not exceed $75 \%$ of the expected volume increment of all the stands excluded from the final cuttings. This proposal, irrespective of better consideration of the actual needs of managed stands, also raises concerns as, in the light of the results of the studies cited above, rigid binding of the planned amount of the pre-final cutting with the expected stand volume increment is unreasonable, as it is crucial to start with the age structure of the stands in a given managed forest.

\section{Need to change regulation and ACCOUNTING RULES FOR PRESCRIBED CUTS}

The need to change the rules of regulating the forest use requires correction of the provisions on the total forest use (Ec), including the interpretation of its components. The total forest use includes the final cutting (UR), prefinal cutting (UPR) and incidental cutting (UPRZ).

$$
\mathrm{Ec}=\mathrm{UR}+\mathrm{UPR}+\mathrm{UPRZ}
$$

The following interpretation of the components of the forest use is proposed:

1) final cutting is the prescribed final cutting by volume, performed taking into account the uniformity of resources and improvement of their status (Borecki et al. 2016); this should be determined by the maximum value, i.e. the amount not possible to exceed during the management term,

2) pre-final cutting is the estimated pre-final cutting by volume, determined based on data from the 
State Forest Information System (SILP) on the implementation of the prescribed cuttings (excluding incidental cuttings) in the preceding management term; Eupr (V) is proposed to be determined according to the formula:

$$
\text { Eupr }(\mathrm{V})=\sum \operatorname{Eupr}(\mathrm{P}) \times \text { Wiupr }
$$

where:

Eupr $(\mathrm{P})$ - the obligatory pre-final cuttings by area, defined in prescribed management works for individual age sub-classes (ha),

Wiupr - average index of intensity of the prefinal cutting $\left(\mathrm{m}^{3} / \mathrm{ha}\right)$, defined as the weighted mean of values for individual subclasses, calculated based on cutting implementation data - compiled in SILP database.

At the stage of implementation, there may be discrepancies between the calculated value and the actual forest use, which should not, however, exceed $75 \%$ of the expected volume increase of the stands under prefinal cuttings.

Incidental cutting is estimated based on SILP data from the previous management period, if the magnitude of the cuttings did not necessitate the preparation of an annex to the plan; if the need arises to determine the magnitude of the incidental forest use, it will require a detailed analysis of the reasons behind this and extension of the plan. The incidental cuttings comprise the volume that cannot be qualified as the pre-final cutting. The incidental forest use in the plan implementation may be exceeded in relation to the value assumed in the total cutting, but not more than $20 \%$ of the amount necessitating an annex.

\section{Suggested Changes}

From the entries in subject literature, it is clear that the incidental cuttings included all the tree cuttings caused by unpredictable events, e.g. windthrow, windfall, snowfall (Jedliński after Hausbrandt 1922). The regulation of the pre-final cuttings should, therefore, take into account the causative agent and its negative consequences, so that damage caused in one stand does not require changing the actions in other stands. Categorizing the incidental cuttings together with the final cuttings or those pre-final, and exchangeable compensation pertaining to timber amounts harvested due to different reasons had negative effects on the whole forest. Suspending the pre-final cuttings because of the fact that stand damage occurred somewhere else in the forest is not reasonable.

The pre-final cutting has two functions: tending and sanitation, and consequently there can be distinguished 2 separate types: tending and incidental cuttings. Rutkowski (1988) recognized that the incidental cuttings need to be given priority as an expression of care for good health and sanitary condition of the forest, by removing diseased, dying and dead trees. He also claimed that if someone wants to harvest the expected yield from the forest, in the pre-final cutting schedule, there must be present an excess of volume left behind after sanitation or incidental cuttings. These amounts must be fully regulated. Such a statement should be fully agreed upon, provided that the incidental forest use includes the sanitation cuttings mentioned by Rutkowski (1988), which are somehow improving the previous tending cuttings. However, if the incidental cuttings are caused by for example windbreaks, and require the removal of trees in excess of stand volume increment, they cannot be considered as the pre-final cuttings. Treating them as pre-final in relation to the whole forest area leads to management disturbances in the case of large-scale incidental cuttings in some stands, resulting in insufficient care in other stands. The occurrence of unpredicted factors, leading to the incidental cuttings, has generally nothing in common with tending activities undertaken in forest stands.

The lack of common features between the tending and incidental cuttings causes that they should be examined separately. These should be independent categories of the forest use. The way of defining the incidental cuttings by Rutkowski (1988) is, as previously noted, different from the definition given by Hausbrandt (1922), who argued that "the incidental forest use is a result of unpredictable force majeure" (Hausbrandt 1922). In the situations, where greater damage in forests is caused by abiotic factors (especially wind), and in times of dynamic weather changes, it would seem appropriate to combine both definitions. Thus, the incidental forest use can mean harvesting of wood from diseased, dying and dead 
trees, as well as harvesting due to unpredictable factors. From the abovementioned record, it follows that the incidental cuttings, which by their nature are unpredictable, should not be directly assigned to the prescribed cuttings. The occurrence of the incidental forest use in one stand should not disturb the fulfillment of management needs of other stands. Therefore, the application of the principle of compensation of cuttings is not appropriate.

Following in the footsteps of reasoning by Rutkowski (1988), the essence of the pre-final cutting is the amount of cut down trees that will be less than the expected periodic increase in the stand volume. Due to unpredicted events, the cutting that exceeds the volume increment should be included in the amount of the incidental cutting, not burdensome for the amount of the prescribed pre-final cuttings. By adopting such reasoning, during the implementation of the pre-final cutting in a given management period, there may occur the following situations:

1) if the tending cuttings were carried out according to the plan and no unpredictable events occurred, which required the incidental cutting - the implemented incidental cuttings would be categorized as the pre-final cuttings;

2) if tending cuttings were carried out according to the plan, and there was a necessity of the incidental cutting - the tending treatments would be included in the pre-final cuttings, and those unpredicted would be categorized as the incidental cuttings, with no effect on the prescribed amounts for the forest use;

3) if the planned tending cuttings were not fully realized in a given period, due to unpredictable events leading to the necessity of implementation of the incidental cuttings, the following cases may be distinguished - depending on the extent of damage to the stands:

a) if the completed pre-final cuttings and forced incidental cuttings on the whole did not exceed the expected stand volume increment, then the incidental cuttings would be considered as part of the pre-final cuttings, because in the case of minor damage, there would be possible - to some extent - performing the tending cuttings and maintaining the principle of not exceeding the expected volume increase,

b) if the completed pre-final cuttings and forced cuttings exceeded the expected increment rate, then such cuttings would be included into the incidental cutting, which does not burden the prescribed cutting amounts; in the extreme situation, it may be necessary to completely remove the stand, then the amount of the pre-final cutting by area would be reduced by the area of this stand; the pre-final cuttings by volume would be treated analogously;

4) if in some tree stands, the tending cuttings were not planned, and there is a need to perform the incidental cuttings - all these cuttings would be included into the non-burdensome category of the incidental cuttings.

\section{SUMMARY AND CONCLUSIONS}

The results of the present study show the need for a separate accounting of the final and pre-final yields. The mode of determination of the amount of pre-final cuttings is recommended in the Instruction for Forest Management (2012), which point out the so-called indicative prescription of the pre-final cuttings by volume. It is not accurate enough and may lead to discrepancies between the plan and its implementation. The authors propose the use of a more explicit and legible way of converting the obligatory pre-final cuttings by area using the following formula:

$$
\operatorname{Eupr}(\mathrm{V})=\sum \operatorname{Eupr}(\mathrm{P}) \times \text { Wiupr }
$$

Large objections concern the realization of the prefinal cuttings in the context of categorizing them as the incidental cuttings. The proposed changes in defining the incidental cuttings would allow for more reliable planning and realization of the pre-final cuttings. The prescribed amount of the pre-final cuttings and the classification of selected events into the appropriate categories of cuttings require supervision and control by the forest manager. Based on this study, the following conclusions were drawn:

1. It is necessary to separately account the final and pre-final cuttings.

2. The method of determining the amount of the prefinal cuttings should be corrected, taking into account the expected volume increment of the stands.

3. Pre-final cutting planning should concern the tending cuttings only, excluding the incidental cuttings. 
4. The incidental cuttings should be a separate forest use category and should not affect the implementation of the tending cuttings in the stands.

\section{References}

Borecki T., Pieniak D., Wócik R. 2012. Realizacja użytkowania przedrębnego w Lasach Państwowych w okresie 1999-2004. Sylwan, 156 (11), 848-854.

Borecki T., Stępień E. 2012. Metodyczne przesłanki strategii rozwoju zasobów leśnych w Polsce. Sylwan 156 (12), 914-922.

Borecki T., Stępień E., Wójcik R. 2016. Koncepcja regulacji rozmiaru użytkowania w wielofunkcyjnym gospodarstwie leśnym. Wyd. SGGW, Warszawa.

Hausbrandt J. 1922. Urządzanie Lasu zgodnie z programem wykładów prof. W. Jedlińskiego. Warszawa.

Instrukcja urządzania lasu. 1957. Ministerstwo Leśnictwa i Przemysłu Drzewnego - Państwowe Wydawnictwo Rolnicze i Leśne, Warszawa.

Instrukcja urządzania lasu. 2003. Załącznik do Zarządzenia nr 43 Dyrektora Generalnego Lasów Państwowych z dnia 18 kwietnia 2003 r. Warszawa. Dyrekcja Generalna Lasów Państwowych, Warszawa.

Instrukcja urządzania lasu 2012. Załącznik do Zarządzenia nr 55 Dyrektora Generalnego Lasów Państwowych z dnia 21 listopada 2011 r. Dyrekcja Generalna Lasów Państwowych, Warszawa.

Konieczny A., Zajączkowski S. 1990. Rozmiar użytkowania przedrębnego a przyrost. Las Polski, 18, 4-7.

Kurt A. 1993. Das Nachhaligkeitsprinzip der Forstwirtschaft in Europa. Schweiz. Z. Forstwes., 144 (2), 81-87.
Oesten G. 1993. Anmerkungen zur Nachhaltigkeit als Leitbild fuer naturvertraegliches Wirtschaften. Forstw. Cbl., 112, 313-319.

Pieniak D. 2008. Ocena możliwości wykorzystania danych $\mathrm{z}$ inwentaryzacji zasobów drzewnych w planowaniu okresowym użytkowania przedrębnego w drzewostanach sosnowych. Doctoral thesis, IBL.

Poznański R. 1996. Problematyka trwałości lasu oraz metody jej utrzymania. Sylwan, 140 (8), 19-31.

Raport o stanie lasów w Polsce. 2006. Dyrekcja Generalna Lasów Państwowych, Warszawa.

Rosa W., Smykała J. 1985. Etat użytków przedrębnych - jego znaczenie i metody określania. Las Polski, $2,17-18$.

Rutkowski B. 1971. Problemy regulacji w gospodarstwie leśnym. Sylwan, 115 (3), 1-11.

Rutkowski B. 1988. Problemy regulacji rozmiaru użytkowania przedrębnego z cięć pielęgnacyjnych i cięć przygodnych. Las Polski, 3, 11-13.

Stępień E. 1995. Idea trwałości lasu - nowe treści, problem realizacji. Sylwan, 139 (12), 5-11.

Stępień E. 1998. Quo vadis urządzanie lasu XXI wieku? Sylwan, 142 (5), 23-34.

Szymkiewicz B., Bernadzki E., Zaręba R., Rosa W. 1996. Urządzanie lasu. Cz. I. Podstawy urządzania lasu. Wyd. SGGW, Warszawa.

Ustawa o lasach z dn. 28.09.1991. Dz.U. 1991 Nr 101 poz. 444.

Zarządzenie Dyrektora Generalnego LP nr $30 \mathrm{z}$ dn. 09.05.2014 r.

Zuercher U. 1965. Die Ideee der Nachhaltigkeit unter spezieller Berueckschichtigung der Gesichtspunkte der Forsteinrichtung. Mittteil. Schweiz. Anstalt $f$. das forstl. Versuchswesen, 41 (4), 1-218. 